\title{
Chemical Control of Whitefly and Aphid Insect Pest of French Bean (Phaseolus vulgaris L.)
}

\author{
S. K. Roy ${ }^{1}$, M. S. Ali ${ }^{2}$, F. T. Z. Mony ${ }^{1 *}$, M. S. Islam ${ }^{3}$ and M. A. Matin ${ }^{2}$ \\ Dept. of Entomology ${ }^{1}$ \\ Dept. of Agronomy \\ Dept. of Plant Pathology 3 \\ Sher-e-Bangla Agricultural University, Dhaka, Bangladesh \\ Corresponding author*: mony.sau67@gmail.com
}

\begin{abstract}
An experiment was conducted at Sher-e-Bangla Agricultural University farm to study the efficacy of some insecticides against major insect pests of French bean (Phaseolus vulgaris L.). The treatments of the experiment were $T_{1}$ : Bamper 20SL (Imidacloprid) @ $0.5 \mathrm{ml} \mathrm{L} \mathrm{L}^{-1}, T_{2}$ : Shobicron4 25EC @ $2 \mathrm{ml} \mathrm{L}^{-1}, T_{3}$ : Actara 25WG (Thiamethoxam) @0.3 $\mathrm{g} \mathrm{L}^{-1}, \mathrm{~T}_{4}$ : Chlorpyriphos 20EC@3 $\mathrm{ml} \mathrm{L}^{-1}, T_{5}$ : Sinothrin 10EC (Cypermethrin) $1 \mathrm{ml} \mathrm{L}^{-1}, T_{6}$ : Fortap 50SP (Cartap) @ 3 $\mathrm{g} \mathrm{L}^{-1}$ and $T_{7}$ : Control treatment. Results showed that the lowest number of whitefly plant ${ }^{-1}$ (3.28 at $60 \mathrm{DAS})$ and aphid plant ${ }^{-1}(4.82$ at $60 \mathrm{DAS})$, the lowest infestation intensity by whitefly $(5.92 \%)$ and aphid (14.25\%), the lowest infested bean yield plant ${ }^{-1}$ (52.80 at 60 DAS), highest healthy bean yield plant ${ }^{-1}\left(166.40 \mathrm{~g}^{2} 60 \mathrm{DAS}\right)$, highest total healthy yield $\left(11.28 \mathrm{t} \mathrm{ha}^{-1}\right)$, lowest total infested yield $\left(0.64 \mathrm{t} \mathrm{ha}^{-1}\right)$ and highest gross return (Tk. $\left.232000.00 \mathrm{ha}^{-1}\right)$ were obtained from the use of Chlorpyriphos. The highest percent reduction of whitefly plant ${ }^{-1}(81.44 \%$ at 60 $D A S)$ and aphid plant ${ }^{-1}(80.15 \%$ at $60 \mathrm{DAS})$, highest percent reduction of infested bean yield plant $^{-1}(81.82 \%$ at $60 \mathrm{DAS})$ and highest increase of healthy bean yield plant ${ }^{-1}$ over control $(215.20 \%$ at 60 DAS) were achieved from the same treatment. Hence Chlorpyriphos 20EC performed best to suppress the whitefly and aphid of French bean followed by Fortap 50SP.
\end{abstract}

Key words: Chemical control, Insecticides, Whitefly, Aphid and French bean

\section{Introduction}

French beans (Phaseolus vulgaris L.) are grown by both small and large scale farmers for fresh and processing market. Production is constrained by western flower thrips (Frankliniella occidentalis), bean flower thrips (Megalurothripss jostedti), bean fly or bean stem maggot (Ophiomyia spp.), aphids (Aphis fabae) and whiteflies (Bemisia tabaci).

Picking of French beans begins 9 weeks after sowing and continues for about 3 weeks when the weather is dry (Nderitu and Anyago, 1993). French beans require an optimum temperature range of 16 $-25^{\circ} \mathrm{C}$ (Bunting, 1961) and friable loam soil that is well drained with high levels of organic matter and a $\mathrm{pH}$ of 6.5-7.5. Higher fruit productivity is achieved in cooler weather. Frost, dry winds, long rains and fog periods are harmful (MOALDM, 1995). Irrigation is vital to maintain continuous production (Legget, 1992).

Chemical control is generally being advocated for the management of insect pests of French bean. The control of aphids, jassid and whitefly in Bangladesh is principally carried out by the conventional use of insecticides. Many workers have tried to control this pest with varying degrees of success by frequent application of insecticides as foliar treatments (Chowdhury and Roy, 1975). It is difficult to emphasize the effectiveness of particular synthetic insecticides out of many commercially available 
ones against a certain insect pest. These chemicals should be applied at appropriate dose and at right time against the target pests. For controlling the pests successfully and to save biological agents, judicious application of insecticides is very essential.

In this study efforts were conducted to find out the most effective insecticide in controlling the aphid and whitefly of French bean. The control is very important to reduce losses due to these pests. But we should control these pest causing the least or without environmental pollution. Therefore, this experiment was undertaken for chemical control of Whitefly and Aphid Insect Pest of French bean (Phaseolus vulgaris L.).

\section{Materials and Method}

Location: The experiment was conducted at the experiment field under the Entomology Department of Sher-e-Bangla Agricultural University, Sher-e-Bangla Nagar, Dhaka during the period of January to March 2011.

Treatments: Treatments of the study were assigned as follows: $\mathrm{T}_{1}=$ Bamper 20SL (Imidacloprid) @ $0.5 \mathrm{ml} \mathrm{L}^{-1}, \mathrm{~T}_{2}=$ Shobicron 425EC @ $2 \mathrm{ml} \mathrm{L}^{-1}, \mathrm{~T}_{3}=$ Actara 25WG (Thiamethoxam) @ $0.3 \mathrm{~g} \mathrm{~L}^{-1}, \mathrm{~T}_{4}=$ Chlorpyriphos 20EC @ $3 \mathrm{ml} \mathrm{L}^{-1}, \mathrm{~T}_{5}=$ Sinothrin 10EC (Cypermethrin) $1 \mathrm{ml} \mathrm{L}^{-1}, \mathrm{~T}_{6}=$ Fortap 50SP (Cartap)@ $3 \mathrm{~g} \mathrm{~L}^{-1}$ and $\mathrm{T}_{7}=$ Untreated Control. Insecticides were procured from local market. The experiment was layout in a Randomized Complete Block Design (RCBD) with four replications in the field.

Preparation of experimental plots: A tractor drawn disc plough followed by harrowing opened the land. Tractor drawn labeler was used to level the land. Urea, TSP and MP fertilizers were applied as recommended for bush bean cultivation @ $45 \mathrm{~kg}$ Urea, $140 \mathrm{~kg}$ TSP and $140 \mathrm{~kg}$ MP, respectively per hectare during land preparation. The basal dose of fertilizer and well decomposed cowdung $10 \mathrm{tha}^{-1}$ were mixed into the soil during final land preparation. The whole field was divided into four equal blocks having $1 \mathrm{~m}$ space between the blocks and each block was again sub-divided into 7 plots $(2.5 \mathrm{~m}$ $\times 2 \mathrm{~m}$ each) as treatment plots with $0.6 \mathrm{~m}$ space between them. The spacing was $30 \mathrm{~cm}$ between rows and $40 \mathrm{~cm}$ between plants.

Plants: The French bean seeds (BARI bush bean-1) were collected from Pulse Research Centre, BARI, Joydebpur, Gazipur. The seeds were subjected to germination test before sowing. In all cases, the rate of germination was found to be more than $90 \%$. Three seeds per pit were sown in each plot of the experimental field. Seeds of French bean were sown on 15 January 2011. Bamper, Shobicron, Actara, Chlorpyriphos, Sinothrin and Fortap were sprayed in assigned plots at 15, 35 and 55 days after germination of plant and dosages by using Knapsack sprayer. Spray materials were applied uniformly to obtain complete coverage of whole plants of the assigned plots. Caution was taken to avoid any drift of the spray mixture to the adjacent plots at the time of the spray application. At each spray application the spray mixture was freshly prepared.

Data collection: After five days of spray, data was collected on the following parameters, incidence of whitefly plant ${ }^{-1}$ by number, incidence of aphid plant ${ }^{-1}$ by number, weight of infested bean plant ${ }^{-1}$, weight of healthy bean plant $\mathrm{t}^{-1}$, total healthy yield $\left(\mathrm{t} \mathrm{ha}^{-1}\right)$, total infested yield $\left(\mathrm{t} \mathrm{ha}^{-1}\right)$ and gross return $\left(\right.$ taka ha $\left.^{-1}\right)$.

$\%$ reduction over control $=\frac{S-T}{S} \times 100$

$\%$ increase over control $=\frac{T-S}{S} \times 100$

Here, $\mathrm{S}=$ Value of sole treatment, $\mathrm{T}=$ Value of treated treatment (without sole treatment)

Infestation intensity was calculated by the following formula: 
Infestation intensity $=\frac{P_{1-P_{2}}}{P_{1}} \times 100$

Here, $\quad P_{1}=$ Number of total plant plot $^{-1}, P_{2}=$ Number of infested plant plot $^{-1}$. Gross return $=$ Total production $(\mathrm{kg}) \times$ Price per $\mathrm{kg}(\mathrm{Tk}$.)

Statistical analysis: All data were analyzed by MSTAT-C software for analysis of variance (ANOVA). Treatment means were separated by applying Least Significant Difference (LSD) test.

\section{Results and Discussion}

\section{Incidence of whitefly at different days after sowing}

Insecticidal application had a significant effect on the incidence of whitefly in French bean (Table 1). With the application of different insecticides, the number of whitefly was gradually decreased over time. The lowest incidence of whitefly $(10.12,5.58,3.28$ and 1.24 per plant at 20,40,60 DAS and at harvest respectively) was observed in the plot treated with Chlorpyriphos 20EC which was statistically similar with Fortap 50SP (Cartap) @ $3 \mathrm{~g} \mathrm{~L}^{-1} / 1 \mathrm{ml} \mathrm{L}^{-1}$ at 20 DAS (10.24) but closely followed at 40, 60 DAS and per plant at harvest $(6.84,5.12$ and 2.84 respectively). It was also evident that of other treatments effect in terms of whitefly incidence was significantly different from Chlorpyriphos 20EC. On the other hand, the highest incidence of whitefly in the crop field (13.44, 15.46, 17.67 and 22.12 per plant at 20,40,60 DAS and at harvest respectively) was found in control treatment $\left(\mathrm{T}_{7}\right)$ which was also significantly different from all other treatments. Among the treated six treatments (without control), the highest incidence of whitefly $(12.38,11.15,9.18$ and 4.12 per plant at 20,40,60 DAS and at harvest respectively) was observed in the treatment of Actara 25WG @ $0.3 \mathrm{~g}$ $\mathrm{L}^{-1}\left(\mathrm{~T}_{3}\right)$ and $\mathrm{T}_{2}$ (Shobicron 425EC @ $2 \mathrm{ml} \mathrm{L}^{-1}$ ) and $\mathrm{T}_{5}$ (Sinothrin 10EC @ $1 \mathrm{ml} \mathrm{L}^{-1}$ ) showed moderate results. The result has also similarity with the findings of Raja (2005).

Table 1. Incidence of whitefly on different insecticides application in French bean at different days after sowing (DAS)

\begin{tabular}{c|c|c|c|c}
\hline \multirow{2}{*}{ Treatment } & \multicolumn{4}{|c}{ Incidence of whitefly $\left(\right.$ No. plant $\left.{ }^{-1}\right)$} \\
\cline { 2 - 5 } & $20 \mathrm{DAS}$ & $40 \mathrm{DAS}$ & $60 \mathrm{DAS}$ & At harvest \\
\hline $\mathrm{T}_{1}$ & $10.36 \mathrm{~d}$ & $8.15 \mathrm{e}$ & $6.98 \mathrm{e}$ & $3.18 \mathrm{~d}$ \\
$\mathrm{~T}_{2}$ & $12.14 \mathrm{~b}$ & $10.04 \mathrm{c}$ & $8.14 \mathrm{c}$ & $3.98 \mathrm{c}$ \\
$\mathrm{T}_{3}$ & $12.38 \mathrm{~b}$ & $11.15 \mathrm{~b}$ & $9.18 \mathrm{~b}$ & $4.12 \mathrm{~b}$ \\
$\mathrm{~T}_{4}$ & $10.12 \mathrm{~d}$ & $5.58 \mathrm{~g}$ & $3.28 \mathrm{~g}$ & $1.24 \mathrm{f}$ \\
$\mathrm{T}_{5}$ & $12.00 \mathrm{bc}$ & $9.12 \mathrm{~d}$ & $7.32 \mathrm{~d}$ & $3.67 \mathrm{c}$ \\
$\mathrm{T}_{6}$ & $10.24 \mathrm{~d}$ & $6.84 \mathrm{f}$ & $5.12 \mathrm{f}$ & $2.84 \mathrm{e}$ \\
$\mathrm{T}_{7}$ & $13.44 \mathrm{a}$ & $15.46 \mathrm{a}$ & $17.67 \mathrm{a}$ & $22.12 \mathrm{a}$ \\
\hline $\mathrm{LSD}_{0.05}$ & 0.038 & 0.244 & 0.146 & 0.044 \\
\hline $\mathrm{CV}(\%)$ & 7.288 & 7.846 & 8.554 & 7.244 \\
\hline $\mathrm{SE}$ & 0.148 & 0.064 & 0.054 & 0.062 \\
\hline
\end{tabular}

Figures in the same column accompanied by the same letter(s) are not significantly different at $5 \%$ level as per Least Significant Difference (LSD) test. Values are mean of three replications.

\section{Incidence of whitefly at different days after sowing}

Variation was observed in terms of percent reduction of whitefly incidence over control by number as influenced by different treatment application (Table 2). It was observed that the highest reduction of whitefly over control (24.70, 63.91, 81.44 and $94.39 \%$ at 20,40, 60 DAS and at harvest respectively) was observed with Chlorpyriphos 20EC @ $3 \mathrm{ml} \mathrm{L}^{-1}\left(\mathrm{~T}_{4}\right)$ where the lowest $(7.88,27.88,48.05$ and $81.37 \%$ at 20, 40, $60 \mathrm{DAS}$ and at harvest respectively) was observed in Actara $25 \mathrm{WG} @ 0.3 \mathrm{~g} \mathrm{~L}^{-1}\left(\mathrm{~T}_{3}\right)$ which was very close to Shobicron 425EC @ $2 \mathrm{ml} \mathrm{L}^{-1}\left(\mathrm{~T}_{2}\right)$ and Sinothrin 10EC (Cypermethrin) $1 \mathrm{ml}$ $\mathrm{L}^{-1}\left(\mathrm{~T}_{5}\right)$. Treatment $\mathrm{T}_{1}$ Bamper 20SL (Imidacloprid) @ $0.5 \mathrm{ml} \mathrm{L}^{-1}$ and $\mathrm{T}_{6}$ Fortap 50SP (Cartap) @ $3 \mathrm{~g}$ 
$\mathrm{L}^{-1}$ ) showed moderate results compared to higher percent reduction of whitefly over control. The order of the effectiveness among the treatments was Chlorpyriphos 20EC @ $3 \mathrm{ml} \mathrm{L}^{-1}\left(\mathrm{~T}_{4}\right)>$ Fortap 50SP (Cartap) @ $3 \mathrm{~g} \mathrm{~L}^{-1}\left(\mathrm{~T}_{6}\right)>$ Bamper 20SL (Imidacloprid) @ 0.5 $\mathrm{ml} \mathrm{L}^{-1}\left(\mathrm{~T}_{1}\right)>$ Sinothrin 10EC (Cypermethrin) $1 \mathrm{ml} \mathrm{L}^{-1}\left(\mathrm{~T}_{5}\right)>$ Shobicron 425EC @ $2 \mathrm{ml} \mathrm{L}^{-1}\left(\mathrm{~T}_{2}\right)>$ Actara 25WG @ $0.3 \mathrm{~g} \mathrm{~L}^{-1}\left(\mathrm{~T}_{3}\right)$ at the time of all growth stages. This result was in agreement with the findings Eapen (1994).

Table 2. Percent reduction of whitefly incidence over control as influenced by different insecticide application

\begin{tabular}{c|c|c|c|c}
\hline \multirow{2}{*}{ Treatment } & \multicolumn{4}{|c}{ Percent reduction over control } \\
\cline { 2 - 5 } & $20 \mathrm{DAS}$ & $40 \mathrm{DAS}$ & $60 \mathrm{DAS}$ & At harvest \\
\hline $\mathrm{T}_{1}$ & $22.92 \mathrm{c}$ & $47.28 \mathrm{c}$ & $60.50 \mathrm{c}$ & $85.62 \mathrm{c}$ \\
$\mathrm{T}_{2}$ & $9.67 \mathrm{e}$ & $35.06 \mathrm{e}$ & $53.93 \mathrm{e}$ & $82.01 \mathrm{e}$ \\
$\mathrm{T}_{3}$ & $7.89 \mathrm{f}$ & $27.88 \mathrm{f}$ & $48.05 \mathrm{f}$ & $81.37 \mathrm{e}$ \\
$\mathrm{T}_{4}$ & $24.70 \mathrm{a}$ & $63.91 \mathrm{a}$ & $81.44 \mathrm{a}$ & $94.39 \mathrm{a}$ \\
$\mathrm{T}_{5}$ & $10.71 \mathrm{~d}$ & $41.01 \mathrm{~d}$ & $58.57 \mathrm{~d}$ & $83.41 \mathrm{~d}$ \\
$\mathrm{~T}_{6}$ & $23.81 \mathrm{~b}$ & $55.76 \mathrm{~b}$ & $71.02 \mathrm{~b}$ & $87.16 \mathrm{~b}$ \\
$\mathrm{~T}_{7}$ & -- & -- & -- & -- \\
\hline $\mathrm{LSD}_{0.05}$ & 0.312 & 1.283 & 1.628 & 1.344 \\
\hline $\mathrm{CV}(\%)$ & 7.816 & 8.144 & 8.327 & 7.452 \\
\hline $\mathrm{SE}$ & 0.116 & 0.068 & 0.059 & 0.060 \\
\hline
\end{tabular}

Figures in the same column accompanied by the same letter(s) are not significantly different at $5 \%$ level as per Least Significant Difference (LSD) test. Values are mean of three replications.

\section{Incidence of whitefly at different days after sowing}

Incidence of aphid in the crop field had significantly affected due to different insecticide application (Table 3). Gradually decreased trend was found for controlling aphid with the application of different insecticide. It was observed that the lowest incidence of aphid $(10.04,6.67,4.82$ and 2.18 per plant at 20, 40, 60 DAS and at harvest respectively) was observed in the plot that was treated with Chlorpyriphos 20EC @ $3 \mathrm{ml} \mathrm{L}^{-1}\left(\mathrm{~T}_{4}\right)$ which was significantly different from all other treatments. On the other hand, the highest incidence of aphid in the crop field (13.36, 18.32, 24.28 and 28.00 per plant at 20, 40, 60 DAS and at harvest respectively) was found in control treatment $\left(\mathrm{T}_{7}\right)$ which was also significantly different from all other treatments. Among the treated six treatment (without control), the highest incidence of aphid (12.22, 10.18, 8.32 and 5.54 per plant at 20, 40, 60 DAS and at harvest respectively) was observed in the treatment of Actara $25 \mathrm{WG} @ 0.3 \mathrm{~g} \mathrm{~L}^{-1}\left(\mathrm{~T}_{3}\right)$ and $\mathrm{T}_{1}$ Bamper 20SL (Imidacloprid) @ $0.5 \mathrm{ml} \mathrm{L}^{-1}$ ) and $\mathrm{T}_{6}$ Fortap 50SP (Cartap) @ $3 \mathrm{~g} \mathrm{~L}^{-1}$ showed moderate results. The result was also supported by Srivastrava and Gupta (1992) and Nawrocka (2003).

Table 3. Incidence of aphid on different insecticides application in bean aphid controlling in French bean at different days after sowing (DAS)

\begin{tabular}{c|c|c|c|c}
\hline \multirow{2}{*}{ Treatment } & \multicolumn{4}{|c}{ Incidence of aphid (No. plant $\left.{ }^{-1}\right)$} \\
\cline { 2 - 5 } & $20 \mathrm{DAS}$ & $40 \mathrm{DAS}$ & $60 \mathrm{DAS}$ & At harvest \\
\hline $\mathrm{T}_{1}$ & $11.07 \mathrm{~d}$ & $8.12 \mathrm{e}$ & $6.36 \mathrm{e}$ & $4.12 \mathrm{e}$ \\
$\mathrm{T}_{2}$ & $11.88 \mathrm{c}$ & $9.26 \mathrm{c}$ & $7.45 \mathrm{c}$ & $5.34 \mathrm{bc}$ \\
$\mathrm{T}_{3}$ & $12.22 \mathrm{~b}$ & $10.18 \mathrm{~b}$ & $8.32 \mathrm{~b}$ & $5.54 \mathrm{~b}$ \\
$\mathrm{~T}_{4}$ & $10.04 \mathrm{f}$ & $6.67 \mathrm{~g}$ & $4.82 \mathrm{~g}$ & $2.18 \mathrm{~g}$ \\
$\mathrm{~T}_{5}$ & $11.65 \mathrm{~cd}$ & $8.84 \mathrm{~d}$ & $7.16 \mathrm{~cd}$ & $4.85 \mathrm{~d}$ \\
$\mathrm{~T}_{6}$ & $10.62 \mathrm{e}$ & $7.86 \mathrm{f}$ & $5.18 \mathrm{f}$ & $3.14 \mathrm{f}$ \\
$\mathrm{T}_{7}$ & $13.36 \mathrm{a}$ & $18.32 \mathrm{a}$ & $24.28 \mathrm{a}$ & $28.00 \mathrm{a}$ \\
\hline $\mathrm{LSD}_{0.05}$ & 0.184 & 0.146 & 0.074 & 0.068 \\
\hline $\mathrm{CV}(\%)$ & 7.478 & 6.842 & 8.394 & 8.149 \\
\hline $\mathrm{SE}$ & 0.088 & 0.176 & 0.144 & 0.188 \\
\hline
\end{tabular}

Figures in the same column accompanied by the same letter(s) are not significantly different at $5 \%$ level as per Least Significant Difference (LSD) test. Values are mean of three replications. 


\section{Incidence of whitefly at different days after sowing}

As mentioned in Table 4, considerable difference was observed in terms of percent reduction of aphid incidence among the treatments over control by number as influenced by different treatment application. It was observed that the highest reduction of aphid over control $(24.85,63.59,80.15$ and $92.21 \%$ at 20, 40,60 DAS and at harvest respectively) was observed with Chlorpyriphos 20EC @ 3 $\mathrm{ml} \mathrm{L}^{-1}\left(\mathrm{~T}_{4}\right)$ where the lowest $(8.53,44.43,65.73$ and $80.21 \%$ at $20,40,60$ DAS and at harvest respectively) was observed in Actara 25WG @ $0.3 \mathrm{~g} \mathrm{~L}^{-1}\left(\mathrm{~T}_{3}\right)$. The treatment, $\mathrm{T}_{2}$ Shobicron 425EC @ $2 \mathrm{ml} \mathrm{L}^{-1}$, and $\mathrm{T}_{5}$ Sinothrin 10EC (Cypermethrin) showed comparatively less efficient results but $\mathrm{T}_{1}$ Bamper 20SL (Imidacloprid) @ $0.5 \mathrm{ml} \mathrm{L}^{-1}$ ) and $\mathrm{T}_{6}$ Fortap 50SP (Cartap) @ $3 \mathrm{~g} \mathrm{~L}^{-1}$ ) showed comparatively higher performance. The order of the effectiveness among the treatments was Chlorpyriphos 20EC @ $3 \mathrm{ml} \mathrm{L}^{-1}\left(\mathrm{~T}_{4}\right)>$ Fortap 50SP (Cartap) @ $3 \mathrm{~g} \mathrm{~L}^{-1}\left(\mathrm{~T}_{6}\right)>$ Bamper $20 \mathrm{SL}$ (Imidacloprid) @ $0.5 \mathrm{ml} \mathrm{L}^{-1}\left(\mathrm{~T}_{1}\right)>$ Sinothrin 10EC (Cypermethrin) $1 \mathrm{ml} \mathrm{L}^{-1}\left(\mathrm{~T}_{5}\right)>$ Shobicron 425EC @ $2 \mathrm{ml} \mathrm{L}^{-1}\left(\mathrm{~T}_{2}\right)>$ Actara 25WG @ $0.3 \mathrm{~g} \mathrm{~L}^{-1}\left(\mathrm{~T}_{3}\right)$ at the time of all growth stages. This result was in agreement with the findings of Brar et al. (1993).

Table 4. Percent reduction of aphid incidence among the treatments over control as influenced by different insecticide application

\begin{tabular}{c|c|c|c|c}
\hline \multirow{2}{*}{ Treatment } & \multicolumn{4}{|c}{ Percent reduction over control } \\
\cline { 2 - 5 } & $20 \mathrm{DAS}$ & $20 \mathrm{DAS}$ & $20 \mathrm{DAS}$ & $20 \mathrm{DAS}$ \\
\hline $\mathrm{T}_{1}$ & $17.14 \mathrm{c}$ & $17.14 \mathrm{c}$ & $17.14 \mathrm{c}$ & $17.14 \mathrm{c}$ \\
$\mathrm{T}_{2}$ & $11.08 \mathrm{e}$ & $11.08 \mathrm{e}$ & $11.08 \mathrm{e}$ & $11.08 \mathrm{e}$ \\
$\mathrm{T}_{3}$ & $8.533 \mathrm{f}$ & $8.533 \mathrm{f}$ & $8.533 \mathrm{f}$ & $8.533 \mathrm{f}$ \\
$\mathrm{T}_{4}$ & $24.85 \mathrm{a}$ & $24.85 \mathrm{a}$ & $24.85 \mathrm{a}$ & $24.85 \mathrm{a}$ \\
$\mathrm{T}_{5}$ & $12.80 \mathrm{~d}$ & $12.80 \mathrm{~d}$ & $12.80 \mathrm{~d}$ & $12.80 \mathrm{~d}$ \\
$\mathrm{~T}_{6}$ & $20.51 \mathrm{~b}$ & $20.51 \mathrm{~b}$ & $20.51 \mathrm{~b}$ & $20.51 \mathrm{~b}$ \\
$\mathrm{~T}_{7}$ & -- & -- & -- & -- \\
\hline $\mathrm{LSD}_{0.05}$ & 0.864 & 0.864 & 0.864 & 0.864 \\
\hline $\mathrm{CV}(\%)$ & 7.064 & 7.064 & 7.064 & 7.064 \\
\hline $\mathrm{SE}$ & 0.072 & 0.072 & 0.072 & 0.072 \\
\hline
\end{tabular}

Figures in the same column accompanied by the same letter(s) are not significantly different at $5 \%$ level as per Least Significant Difference (LSD) test. Values are mean of three replications.

Weight of infested and healthy bean yield plant ${ }^{-1}$, percent reduction and increase of infested bean yield plant ${ }^{-1}$ over control were significantly influenced by different insecticides application mentioned in different treatments (Table 5). Results indicated that the lowest infested bean yield plant $^{-1}(9.60 \mathrm{~g}$ at 60 DAS) was achieved by the treatment of Chlorpyriphos 20EC @ $3 \mathrm{ml} \mathrm{L}^{-1}\left(\mathrm{~T}_{4}\right)$ which was significantly different from all other treatments. On the other hand, the highest infested bean yield plant $^{-1}(52.80 \mathrm{~g}$ at $60 \mathrm{DAS})$ was obtained from control treatment $\left(\mathrm{T}_{7}\right)$. But among the treated plot (without control), the highest infested bean yield plant $^{-1}$ (45.60 and $63.20 \mathrm{~g}$ at 60 and 85 DAS) was observed in $\mathrm{T}_{3}$ (Actara 25WG @ $0.3 \mathrm{~g} \mathrm{~L}^{-1}$ ) which was closely followed by $\mathrm{T}_{5}$ Sinothrin10EC (Cypermethrin)@1 $\mathrm{ml} \mathrm{L}^{-1}$. The highest percent reduction over control (81.82\% at 60 DAS) was observed in $\mathrm{T}_{4}$ (Chlorpyriphos 20EC @ $3 \mathrm{ml} \mathrm{L}^{-1}$ ) where the lowest percent reduction over control (13.64 and 8.14\% at 60 and 85 DAS) was obtained from $\mathrm{T}_{3}$ (Actara 25WG @ $0.3 \mathrm{~g} \mathrm{~L}^{-1}$ ). The treatment $\mathrm{T}_{6}$ (Fortap 50SP (Cartap) @ $3 \mathrm{~g} \mathrm{~L}^{-1}$ ) also showed comparatively higher percent reduction of infested bean yield plant ${ }^{-1}$ over control (66.67 and 51.17\% at 60 and 85 DAS). The highest healthy bean yield plant ${ }^{-1}(166.40 \mathrm{~g}$ at 60 DAS) was achieved by the treatment of Chlorpyriphos 20EC @ $3 \mathrm{ml}$ $\mathrm{L}^{-1}\left(\mathrm{~T}_{4}\right)$ which was significantly different from all other treatments. Again, the second highest per plant healthy yield plant ${ }^{-1}$ (159.20 and $205.60 \mathrm{~g}$ at 60 and $85 \mathrm{DAS}$ ) was achieved from $\mathrm{T}_{6}$ (Fortap 50SP (Cartap)@ $3 \mathrm{~g} \mathrm{~L}^{-1}$ ) which was also significantly different from all other treatments. On the other hand, the lowest healthy bean yield plant ${ }^{-1}$ (52.80 and $102.40 \mathrm{~g}$ at 60 and 85 DAS) was obtained from control treatment $\left(\mathrm{T}_{7}\right)$. The highest percent increase over control $(215.20 \%$ at $60 \mathrm{DAS})$ was 
observed in $\mathrm{T}_{4}$ (Chlorpyriphos 20EC @ $3 \mathrm{ml} \mathrm{L}^{-1}$ ) where the lowest percent increase over control $\left(83.33 \%\right.$ at 60 DAS) was obtained from $\mathrm{T}_{3}$ (Actara $25 \mathrm{WG} @ 0.3 \mathrm{~g} \mathrm{~L}^{-1}$ ). The treatment $\mathrm{T}_{6}$ Fortap 50SP (Cartap) @ $3 \mathrm{~g} \mathrm{~L}^{-1}$ also showed comparatively higher percent increase of healthy bean yield plant $^{-1}$ over control (201.50 and $100.80 \%$ at 60 and 85 DAS). This result was in agreement with the findings of Kumar and Sharma (2003).

Table 5. Effect of different insecticides application in controlling of insect pest in French bean on weight of infested and healthy bean at different days after sowing (60 DAS)

\begin{tabular}{c|c|c|c|c}
\hline Treatment & $\begin{array}{c}\text { Weight of infested } \\
\text { bean (g)plant }\end{array}$ & $\begin{array}{c}\text { Percent reduction } \\
\text { over control }\end{array}$ & $\begin{array}{c}\text { Weight of healthy } \\
\text { bean }(\mathrm{g}) \text { plant }^{-1}\end{array}$ & $\begin{array}{c}\text { Percent increase } \\
\text { over control }\end{array}$ \\
\hline $\mathrm{T}_{1}$ & $35.20 \mathrm{~d}$ & $33.33 \mathrm{c}$ & $126.00 \mathrm{c}$ & $138.60 \mathrm{c}$ \\
$\mathrm{T}_{2}$ & $40.80 \mathrm{c}$ & $22.73 \mathrm{e}$ & $107.20 \mathrm{e}$ & $103.00 \mathrm{e}$ \\
$\mathrm{T}_{3}$ & $45.60 \mathrm{~b}$ & $13.64 \mathrm{f}$ & $96.80 \mathrm{f}$ & $83.330 \mathrm{f}$ \\
$\mathrm{T}_{4}$ & $9.60 \mathrm{f}$ & $81.82 \mathrm{a}$ & $166.40 \mathrm{a}$ & $215.20 \mathrm{a}$ \\
$\mathrm{T}_{5}$ & $39.20 \mathrm{c}$ & $25.76 \mathrm{~d}$ & $116.80 \mathrm{~d}$ & $121.20 \mathrm{~d}$ \\
$\mathrm{~T}_{6}$ & $17.60 \mathrm{e}$ & $66.67 \mathrm{~b}$ & $159.20 \mathrm{~b}$ & $201.50 \mathrm{~b}$ \\
$\mathrm{~T}_{7}$ & $52.80 \mathrm{a}$ & -- & $52.80 \mathrm{~g}$ & -- \\
\hline $\mathrm{LSD}_{0.05}$ & 2.361 & 1.112 & 3.68 & 4.8520 \\
\hline $\mathrm{CV}(\%)^{\mathrm{SE}}$ & 7.549 & 7.038 & 8.32 & 7.92 \\
\hline
\end{tabular}

Figures in the same column accompanied by the same letter(s) are not significantly different at $5 \%$ level as per Least Significant Difference (LSD) test. Values are mean of three replications.

Table 6. Effect of different insecticides application in controlling of insect pest in French bean on marketable yield and economic returns

\begin{tabular}{c|c|c|c}
\hline Treatment & Total healthy yield $\left(\mathrm{t} \mathrm{ha}^{-1}\right)$ & Total infested yield $\left(\mathrm{t} \mathrm{ha}^{-1}\right)$ & Gross return $\left(\mathrm{Tk} \mathrm{ha}^{-1}\right)$ \\
\hline $\mathrm{T}_{1}$ & $7.44 \mathrm{c}$ & $2.24 \mathrm{c}$ & $171200.00 \mathrm{c}$ \\
$\mathrm{T}_{2}$ & $6.74 \mathrm{de}$ & $2.54 \mathrm{c}$ & $160200.00 \mathrm{e}$ \\
$\mathrm{T}_{3}$ & $6.18 \mathrm{e}$ & $2.72 \mathrm{~b}$ & $150800.00 \mathrm{f}$ \\
$\mathrm{T}_{4}$ & $11.28 \mathrm{a}$ & $0.64 \mathrm{e}$ & $232000.00 \mathrm{a}$ \\
$\mathrm{T}_{5}$ & $7.04 \mathrm{c}$ & $2.36 \mathrm{~d}$ & $164400.00 \mathrm{~d}$ \\
$\mathrm{~T}_{6}$ & $9.12 \mathrm{~b}$ & $1.28 \mathrm{~d}$ & $195200.00 \mathrm{~b}$ \\
$\mathrm{~T}_{7}$ & $3.88 \mathrm{f}$ & $3.04 \mathrm{a}$ & $108000.00 \mathrm{~g}$ \\
\hline $\mathrm{LSD}_{0.05}$ & 0.538 & 0.129 & 13.196 \\
$\mathrm{CV}(\%)$ & 7.843 & 6.348 & 8.142 \\
\hline $\mathrm{SE}$ & 0.114 & 0.118 & 0.129 \\
\hline
\end{tabular}

Figures in the same column accompanied by the same letter(s) are not significantly different at 5\% level as per Least Significant Difference (LSD) test. Values are mean of three replications.

Total healthy yield, total infested yield and gross return were significantly influenced by different insecticide application mentioned in different treatments (Table 6). Results indicated that the highest healthy bean yield ha ${ }^{-1}\left(11.28 \mathrm{t} \mathrm{ha}^{-1}\right)$ was achieved by the treatment of Chlorpyriphos 20EC @ $3 \mathrm{ml} \mathrm{L}$ ${ }^{1}\left(\mathrm{~T}_{4}\right)$ which was significantly different from all other treatments. On the contrary, the lowest healthy bean yield ha- $\mathrm{ha}^{-1}\left(3.88 \mathrm{tha}^{-1}\right)$ was obtained from control treatment $\left(\mathrm{T}_{7}\right)$. The lowest infested bean yield $\mathrm{ha}^{-1}\left(0.64 \mathrm{t} \mathrm{ha}^{-1}\right)$ was achieved by the treatment of Chlorpyriphos 20EC @ $3 \mathrm{ml} \mathrm{L}^{-1}\left(\mathrm{~T}_{4}\right)$ which was significantly different from all other treatments. Furthermore, the highest infested bean yield $\mathrm{ha}^{-1}$ (3.04 t ha $\left.{ }^{-1}\right)$ was obtained from control treatment $\left(\mathrm{T}_{7}\right)$. From the economic point of view, effective pest management of a crop application of different causes a great gross return. Under the present study applied insecticides showed variable performance for managing the insect pests of French bean 
(Table 6). The affectivity was not same and varied significantly and this is why a great variation was occurred in terms of gross return. Results showed that the highest gross return (Tk. $232000.00 \mathrm{ha}^{-1}$ ) was achieved from Chlorpyriphos 20EC @ $3 \mathrm{ml} \mathrm{L}^{-1}\left(\mathrm{~T}_{4}\right)$ treated plot, whereas the lowest gross return (Tk. $108000.00 \mathrm{ha}^{-1}$ ) came from control treatment. The second highest gross return Tk. 195200.00 ha${ }^{1}$ ) was observed from Fortap 50SP (Cartap) @ $3 \mathrm{~g} \mathrm{~L}^{-1}$ treated plot $\left(\mathrm{T}_{6}\right)$ which was close to the treatment of $\mathrm{T}_{1}$ (Bamper 20SL (Imidacloprid) @ $0.5 \mathrm{ml} \mathrm{L}^{-1}$ ) treated plot (Tk. $171200.00 \mathrm{ha}^{-1}$ ). Under the treated plot, the lowest gross return (Tk. $150800.00 \mathrm{ha}^{-1}$ ) was observed from Actara 25WG @ 0.3 $\mathrm{gL}^{-1}\left(\mathrm{~T}_{3}\right)$.

\section{Conclusion}

It may be concluded that incidence of whitefly and bean aphid was lowest with application of Chlorpyriphos 20EC @ $3 \mathrm{ml} \mathrm{L}^{-1}$. Highest total healthy fruit yield, lowest infested fruits and highest gross return were found from Chlorpyriphos application while control showed lowest performance. Thus, Chlorpyriphos 20EC @ $3 \mathrm{ml} \mathrm{L}^{-1}$ could be recommended for chemical control of whitefly and aphid insect infesting French bean.

\section{References}

Brar, K. S., Dhillon, G. S. \& Singh, M. (1993). Control of pea stem fly, Ophiomyia phaseoli Tryon in early crop of pea. Indian J. Entomol. 55 (2): 210-211.

Bunting, A. H. (1961). Some problems of Agricultural Climatology. Tropical Africa Geography. 46: 283-294.

Chowdhury, R. \& Roy, C. S. (1975). Evaluation and economies of some insecticides for the control of mustard aphid, L. erysimi Kalt. on rabi B. juncea. Indian J. Entomol. 37(3): 264-68.

Eapen, S. J. (1994). Effect of three granular pesticides on damage by thrips (Sciothrips cardamomi R.) in small cardamom (Elettaria cardamomum M.). J. Entomol. Res. 18 (2): 181-183.

Kumar, A. \& Sharma, R. C. (2003). Management of pea stem fly Ophiomyia phaseoli by chemical control. Indian J. Entomol. 65(4): 566-568.

Legget, J. E. (1992). The influence of UNV Malathion applied for pest and disease control in Arizona 1986-1990. Southwestern Entomol.17: 49-61.

MOALDM. (1995). Kenya reports on the agriculture sector review and an outline of tentative investment, strategy. Draft Report Ministry of Agriculture, Livestock Development and Marketing Nairobi, Kenya, pp. 212

Nawrocka, B. (2003). Economic importance and the control method of Thrips tabaci Lind. on onion. Bulletin OILB/SROP. 26(3): 321-324.

Nderitu, J. H. \& Anyago, J. J. (1993). Survey of diseases and control measures of major pests. Disease of French beans. Proceedings of the 3rd Regional Workshop of Beans Research in Eastern Africa, 19-22 April 1993. Thika, Kenya.

Raja, B. K. (2005). Management of Mung bean pests. Online edition of India's National Newspaper.

Srivastrava, K. J. \& Gupta, R. P. (1992). Studies on effect of systemic insecticides on the control of onion thrips in kharif. Newsletter Associated Agril. Dev. Foun. 12(4): 9-11.

\section{Citation for this article:}

Roy, S. K., Ali, M. S., Mony, F. T. Z., Islam, M. S. \& Matin, M. A. (2014). Chemical Control of Whitefly and Aphid Insect Pest of French Bean (Phaseolus vulgaris L.). Journal of Bioscience and Agriculture Research, 02(02), 69-75.

Retrieved November 07, 2014, from http://www.journalbinet.com/current-issue-jbar-1.html 